\title{
Study on Counter-Piracy in China Based on the UNCLS
}

\author{
Wang Dan \\ Research Center of Basic Subject Development and Application, Chinese People's Armed Police Force Academy \\ Langfang, China \\ wangdanice@sina.com
}

\begin{abstract}
Increasing piracy has a real threat to the merchant vessels sailing on the ocean, particularly in the Somali waters. Chinese government and International community have realized the great threat and made great efforts to combat the severe situations. Based on careful investigation, this paper explores the current situation of international community fighting against piracy and contemporary international legal regime for countering piracy. Moreover, some countermeasures are discussed, including the legislation development and countermeasures in China to fight piracy and to establish cooperation mechanism.
\end{abstract}

\section{Keywords-Piracy; Counter-piracy; Countermeasures; Cooperation}

\section{INTRODUCTION}

With the growth of the global economy, the sea and oceans for trade has increased dramatically, therefore, maritime transport activity plays more and more important role. However, piracy attack has disturbed the peace and stability on the sea, posed great danger and threat to the life of crewmembers and brought great loss to the country and ship owner. What measures we should take and how to make joint efforts with worldwide organizations to fight against piracy attack becomes the hot topic under current situation.

\section{BACKGROUND INFORMATION}

\section{A. Definition of piracy}

All the above documents have a clear definition about the term of piracy. In the UN Convention of Law of the Sea in 1982, piracy "consists of any of the following acts: (a) any illegal acts of violence or detention, or any act of depredation, committed for private ends by the crew or the passengers of a private ship or a private aircraft, and directed: (i) on the high seas, against another ship or aircraft, or against persons or property on board such ship or aircraft; (ii) against a ship, aircraft, persons or property in a place outside the jurisdiction of any State; (b) any act of voluntary participation in the operation of a ship or of an aircraft with knowledge of facts making it a pirate ship or aircraft; (c) any act of inciting or of intentionally facilitating an act described in subparagraph (a) or (b) ".

Art. 102 and 103 are supplement to Art. 101 as far as the

This paper is the periodic research result of the project entitled "Study on College English Teaching New Mode”. This project is the Young Teacher Research Innovation Program of Chinese People's Armed Police Force Academy. acts of piracy and a pirate ship or aircraft is concerned. Art. 102 provides that "The acts of piracy, as defined in Art. 101 committed by a warship, government ship or government aircraft whose crew has mutinied and taken control of the ship or aircraft are assimilated to acts committed by a private ship or aircraft".

While Art.103 defines a pirate ship or aircraft as "a pirate ship or aircraft if it is intended by the persons in dominant control to be used for the purpose of committing one of the acts referred to in article 101. The same applies if the ship or aircraft has been used to commit any such act, so long as it remains under the control of the persons guilty of that act".

A conclusion can be reached from the provisions that piracy poses a threat to the international community with a clear characteristic. It is an international danger and it is a criminal offense.

\section{B. Brief introduction to piracy}

Maritime transport is low-cost and convenient. Worldwide 90 percent of global merchandise trade is carried primarily by sea across established international routes and trade lanes. The importance of the sea and oceans for trade has increased with the growth of the world economy, maritime transport activity. However, what happens in the oceans and seas has disturbed the peace and stability on the sea, posed great danger and threat to the life of crewmembers and brought great loss to the ship owner-it is piracy. Piracy is not a new crime, its history can date back to almost 3000 years ago. Piracy emerged at the same time as seaborne traffic. Since then, most of the coasts and busy sea routes of the globe have had to deal with pirate attacks. Though forms, purposes, and modus operandi of piracy have evolved over time, the fundamentals stay the same Piracy relies on a crew, a boat, a base on land, and access to busy shipping routes, harbors, and anchorages.

Like legendry pirates, modern pirates are still involved in looting and hijacking ships for ransom, but their ways of operations has dramatically changed over time. With the development of modern technology, piracy has been more and more perceived as an organized crime regarding the scale, level of sophistication and degree of violence of incidents reported. It has carried every feature of armed organized crime--militarization and internationalization, industrialization and network. Pirates carry heavy machine guns, and rocket 
launchers to rob/hijack shipping vessels; their ships navigate with GPS devices; and they use sophisticated speedboats mounted with heavy mortars to target ships. They are part of organized crime gangs that target big and small cargo vessels, and even cruise ships and private yachts [1].

What has resulted in the problem of piracy? Historically, it partly depends on the social and political situation of a country. However, the most important reason is that of economy. With the declined economy of a country, the problem of piracy would come into being and become more serious along with the deteriorated situation of the country. For example, what caused the severity of the Somali pirates is that the Somalia split shortly after the Somali Civil War. The lack of strong government, poverty of local people, and instability of the society contribute to make more people pirates.

\section{Current situation of international community fighting against piracy}

Piracy off the coast of Somalia has become a threat to international shipping. It not only seriously influences international trade on sea, but also poses a great danger to the life of crewmembers, furthermore, it has hindered maritime transportation. Faced with the intensified situation in the Red Sea and the Gulf of Aden, international community and organizations have shown great concern over the piracy in these regions. The international community has been aware that they can only act together to win back peace and security in these waters.

International organizations have actively engaged in solving the problem. The UN Security Council Resolution 1851 was unanimously adopted on 16 December 2008 that "for the next year, States and regional organizations cooperating in the fight against piracy and armed robbery at sea off Somali coast". Since the end of 2008, there has been an increase in coordinated anti-piracy patrols conducted in the Gulf of Aden. The European Union, the African Union, the League of Arab States, and North Atlantic Treaty Organization (NATO) are all active in fighting piracy off the coast of Somalia. Military and naval forces play an invaluable role in the deterrence and interdiction of piracy and armed robbery at sea. By escorting commercial vessels through high - risk areas, they offer safe passage that protects the vessel, its cargo and its crew against the scourge of piracy, allowing international trade to continue without disruption. Besides, individual forces have also been deployed to provide escort by countries such as China, India, the Islamic Republic of Iran, Russia and son on. The combined patrols have to some extent brought piracy attacks in the areas under patrol [2].

\section{CONTEMPORARY INTERNATIONAL LEGAL REGIME FOR COUNTERING PIRACY}

\section{A. Introduction}

As is known to all, maritime piracy has developed from a localized maritime transport concern and has become a global challenge irrespective any filed. Addressing this challenge in an effective manner requires strong cooperation at the political, economic, legal, diplomatic and military levels, as well as collaboration between diverse public and private sector stakeholders across regions. To some extent, such cooperation has been effective when the international community joined forces to combat piracy. Multilateral cooperation efforts in the region have involved governments, regional organizations, intergovernmental organizations as well as the shipping industry. However, much remains to be achieved.

Despite the significant drop in the number of reported attacks off the coast of Somalia/Gulf of Aden and in other waters, the problem has not gone away. As pointed out by one observer, "the pirates are still there - they haven't gone away, they are just sleeping. It might be contained now, but the networks or individuals involved in piracy could easily go back into piracy depending on the situation".

Countries around the world and international organizations and the like should employ every means they can to address the challenge. However it is not easy to eradicate the problem as obstacles are hindering human being's efforts from a broad range of areas, including economic, financial, political and legal.

\section{B. International conventions/agreements countering piracy}

Following numerous attempts to codify international law provisions on piracy, the Convention on the High Seas was adopted in 1958. The 1958 Convention restates provisions that were considered to be generally declaratory of established principles of international law at that time. The provisions of the 1958 Convention has formed the basis of the 1982 United Nations Convention on the Law of the Sea (UNCLOS) provisions on piracy. These provisions, which are presented below, provide the contemporary international legal framework for countering piracy; they are binding for Contracting States to UNCLOS.

Other conventions that may be of relevance in the repression and effective prosecution of piracy include:

(a) The Convention for the Suppression of Unlawful Acts against the Safety of Maritime Navigation, 1988, and its Protocols;

(b) The International Convention against the Taking of Hostages, 1979;

(c) The United Nations Convention on Transnational Organized Crime, 2000.

(d) The Code of Practice for suppressing piracy and Armed Robbery against Ships adopted by IMO in Djibouti in 2009

(e) The UN Security Council Resolutions concerning piracy.

\section{Perfection of counter-piracy international legal system}

Piracy is an international crime, and countries around the world should take their responsibility to fight against pirates, but their actions should comply with certain legal principle. Operations targeted at piracy by each country should have adequate legal basis. Historically, the UNCLS has become the primary legal document to punish pirate crime with other supplementary legal documents, all of which have 
laid a foundation to stop pirate crime, still a lot needs to be done [3]. Generally, it does not appear that the above Conventions have so far played any major role in punishing piracy over recent years.

Firstly, there is a necessity to revise international legal documents, which are relatively lag as they cannot contribute a helpful effort in punishing pirates, particularly key elements of pirate offence must be broadened. Take the definition of the pirate crime as another example, pirate crime in UNCLOS has a number of core components, most importantly, its geographical and substantive scope. The geographical scope of the definition extends universal jurisdiction to acts of piracy on the high seas and in any other place outside the jurisdiction of any State, along with acts that occur in a State's exclusive economic zone (EEZ), save for acts that occur in a State's territorial waters. Furthermore, it is necessary to redefine the universal jurisdiction mechanism so to effectively punish pirates. For instance, Article 105 of UNCLOS provides universal jurisdiction over those who commit acts that fall within the definition of piracy provided in article 101. Article 105 states: "On the high seas, or in any other place outside the jurisdiction of any State, every State may seize a pirate ship or aircraft, or a ship or aircraft taken by piracy and under the control of pirates, and arrest the persons and seize the property on board. The courts of the State which carried out the seizure may decide upon the penalties to be imposed, and may also determine the action to be taken with regard to the ships, aircraft or property, subject to the rights of third parties acting in good faith. [4]"

Given the above reasons, it is quite urgent to introduce new legal documents as a guideline and principle because there is not a universal convention dedicated to the eradication of piracy. Of course, the national legislation must be quickly developed.

\section{COUNTERMEASURES TO FIGHT PIRACY IN CHINA}

The vessel is the direct victim of the crime of piracy. At present, the most effective measure to fight against piracy is to strengthen risk prevention. The importance in counter-piracy is to take self-rescue as the primary strategy and get external help as an alternative. Therefore, it is essential to take preventative and precarious measures to decrease the loss caused by piracy.

\section{A. Prevention and countermeasures taken by vessels}

(1) To improve and perfect work mechanisms and emergency disposal plans to prevent and crack down piracy and to make emergency plan when ships sail in dangerous waters.

(2) To strengthen cooperation with the navy for escorting so that the navy can arrange professionals to have counterpiracy training for personnel on commercial vessels and aircrafts.

(3) To strengthen training and practical exercise, to improve sailor's emergency response capacity and security consciousness and ability, to increase sailor's confidence to fight with pirates
(4) To improve sailor's quality, to cultivate their courage to resist pirates and learn to defeat pirates with wisdom and intelligence.

(5) To enhance vessel's self-defense ability, to improve the construction of vessel's security infrastructure and finally to exert the vessel's role to the greatest extent.

(6) To adopt and renew safety facilities or equipment on time, to install more advanced devices for prevention and communication and to install high frequency alarm equipment and satellite communication equipment and to promote management of these security devices.

(7) To keep watch and patrol on deck and increase sailor's skill and ability to prevent the happening of piracy.

(8) If pirates attempt to board, sailors should make efforts to prevent them with high pressure water guns, alarm whistles, floodlights and other devices.

(9) When sailing, sailors should keep a close eye on hazardous areas and try to avoid passing through high-risk waters.

(10) To keep calm in the process of negotiation with pirates. In all conditions the safety of the vessels and crew is a priority, to manage to negotiate with pirates effectively.

(11) To accelerate the development of counter-piracy equipment.

(12) To hire private armed guards.

\section{B. Prevention and strategy to improve legal enforcement forces}

(1) To establish National Counter-piracy Joint Command Center[6]. This department should consist of the Ministry of Transport, the Ministry of Public Security, the Ministry of Foreign Affairs, the Central Military Commission, the Ministry of Finance and the Chinese Coast Guard Bureau and etc. as countering piracy involves different institutions. The duty of the command center is to deal with affairs related to piracy, including to coordinate activities with relevant departments, to work out counter-piracy measures, to provide training courses about counter-piracy for crew, to exchange and share information with international organizations and other agencies, to solve judicial problem about piracy. The chief commander should be the deputy prime minister who is in charge of transport department, whose office can be located in the Ministry of Transport [4].

(2) To set up a piracy risk prevention joint fund. Chinese government finance and relevant shipping enterprises make joint contributions to build the fund and China Ship-owners Mutual Assurance Association is delegated by the National Counter-piracy Joint Command Center to manage the operation of funds.

(3) To build law mechanism for sudden piracy incidents. In fighting against pirates, effective legal emergency plans and liability systems should be established and improved.

(4) To pay attention to the construction of navy power and air power, as a result, the Chinese navy and air force are 
capable to combat piracy and protect sea resources and energy supply. It is necessary to exploit overseas supply bases. While undertaking escort commissions, China can take full advantage of harbors around the Indian Ocean. At the same time, China should help to build more relevant harbors off the coastal region of Africa, take them as future supply bases overseas. Be cautious while taking tasks by force. The principle is to make use of force in a proper and legal manner.

(5) To unify law enforcement agencies, establish particular overseas law enforcement teams and strengthen law enforcement power. In order to realize it, overseas police teams must be established. Until now, China has formed maritime police teams. In accordance with relevant laws, maritime police are in charge of security and criminal cases overseas. The crime of piracy is filed and detected by maritime police.

(6) To conduct active cooperation with international communities and regional organizations. It is a tough job to crack down on pirates and cannot be achieved with only one country or region's efforts. The Chinese government should take be more active in cooperation with international organizations, such as the United Nations, international maritime organizations, international maritime bureaus and the United Nations marine organization, etc.

(7) To establish extradition mechanisms linked to international community. All judgment confronts two major problems: high judicature cost right of jurisdiction, the judgment of pirates is not an exception. If there is conflict between our country's judgment and other country's jurisdiction or the judicature cost is too much, extradition of pirates becomes extremely imperative. It has become a tendency to set up effective extradition mechanisms linked to the international community in China.

\section{TO ESTABLISH COOPERATION MECHANISM BETWEEN CHINA AND SOUTHEAST ASIAN NATIONS}

There are two types of cooperation mechanisms in counter piracy: a multilateral cooperation mechanism and a regional cooperation mechanism. The mechanism of multilateral cooperation means that all nations around the world take active part in international conventions and global multilateral agreements, take international responsibility and carry out duties.

In order to solve piracy problems, international communities play an important role as multilateral platforms. For example, global organs, like the United Nations, International Maritime Organization and some nongovernment institutions are promoting all relevant communities to strengthen cooperation in counter-piracy. At present, it is considered to establish international cooperation mechanism guided by the United Nations Security Council or international maritime organizations. Mechanism of regional cooperation means some nations in nearby regions cooperate with each other to fight against pirates. Piracy is often immediate and transnational, which leads to the difficulty to solve problem. Therefore, to cooperate together is no doubt a good solution. Although China and other Southeast Asian nations have not signed any bilateral or multilateral treaty about counter-piracy cooperation, still, it becomes very necessary to make sustainable cooperation between each other. Until now, China has cooperated with many countries with Southeast Asian nations, such as Vietnam, Cambodia, Laos, and Thailand, to fight against pirates together in Mekong River [5].

The following strategies are suggested to construct cooperation mechanism between China and Southeast Asian nations in counter piracy.

(1) To give a uniform definition about "crime of piracy" and composing elements, which can overcome the obstacles to construct relevant legal cooperation mechanism.

(2) To promote the conduct of any multilateral agreements regarding counter-piracy between China and Southeast Asian Nations so to form the basis for the establishment of necessary legal treaties for cooperation.

(3) To strengthen regional judicial cooperation and judicial assistance in counter-piracy between China and Southeast Asian Nations. To be specific, Southeast Asian nations should strengthen cooperation in the aspect of extradition, judicial jurisdiction, delivery of documents, collection and exchange of evidence and etc.

\section{CONCLUSION}

In conclusion, the government of China and Southeast Asian Nations should realize the inefficiency of fighting piracy with their single effort. Instead, all countries should get rid of the fixed pattern in counter-piracy cooperation and make more legislative and systematic cooperation system, form regular long-term cooperation mechanism, learn from successful regional cooperation, such as Malaysia, the Philippines, Vietnam, Thailand and Singapore. China should bring her geographic superiority into full play in aspects of regional cooperation with other Southeast Asian nations and establish cooperation mechanisms. With the help of these mechanisms, piracy crimes in relevant waters will be fought effectively so that the prosperity and development of maritime trade can be guaranteed in China and nearby countries.

\section{REFERENCES}

[1] Edward Lundquist, Is Arming Merchant Ships a Solution? Maritime Reporter, 2009(7).

[2] Yin Rensheng, Zhou Chuanli, Lawful Analysis on the Force Against Somali Pirates by International Society[J], Lanzhou Academic Journal, 2009(4). (In Chinese)

[3] Zhang Xu, International Criminal Law: Current Situation and Prospect. Beijing: Tsinghua University Press, 2005. (In Chinese)

[4] Wang Qiuling, Amendment and Perfection of the Constructive Requirements of Pirate Crime in International Convention, Annual of China Maritime Law, 2008. (In Chinese)

[5] Zhang Jiadong, The Pirate's Activity and the Contruction of International Counter-piracy Mechanism, Contemporary International Relations, 2009(2). (In Chinese) 